\title{
A Complicated Personality in Seize The Day By Saul Bellow
}

\author{
Faruk Kalay (Corresponding author) \\ The Faculty of Education, Muş Alparslan University \\ Guzeltepe Yerleşkesi, 49250, Muş, Turkey \\ E-mail: f.kalay@alparslan.edu.tr
}

Doi:10.7575/aiac.alls.v.6n.1p.1

URL: http://dx.doi.org/10.7575/aiac.alls.v.6n.1p.1
Received: 26/08/2014

Accepted: 04/11/2014

\begin{abstract}
Saul Bellow, a distinctive prominent writer in American literature, is frequently concerned with the themes of Jewish culture, and alienation. In Bellow's novel Seize the Day, Tommy Adler "the maladroit, suffering middle-aged hero of the book, is the pathetic heir in post-war fiction to the failure of the American Dream" (Richmond 15). Tommy abandons his family and endeavors to emulate his father. However, his father's perfectionism and preference for avoidance of his son lead to the protagonist's physical and psychological alienation. Furthermore, the resemblance of their lifestyles and attitudes indicates that their consciousness, sub-conscious, and psychologies follow the same routine. This study will therefore argue the novel's psychoanalytic characteristics.
\end{abstract}

Keywords: Mind Structure, Personality, Psychoanalysis, Saul Bellow, Seize the Day, Tommy Adler, Wilhelm Adler

\section{Introduction}

One of prominent American Jewish authors of the twentieth century, Saul Bellow authored an excellent novel, titled Seize the Day, that recounts one day in the life of the protagonist Tommy/Wilhelm Adler's. Cheuse depicts the novel as "the best short novel by an American" (19). In addition, Allen presumes that the novel is "not a financial success, but it, too, garnered impressive critical notice" (84). Suffering from many psychological problems, Wilhelm/Tommy (Tommy hereafter) is portrayed as a beleaguered character whose milieu seems to be a complication for him. Furthermore, his father, Dr. Adler, comes to the fore from amid the other characters because his relationship with his son possesses a great deal of importance.. However, Alhadeff purports the novel "deals with the neurotic father-son relationship of the novel as a thematic function of Oedipal concerns" (18). In this sense, the novel can be regarded as bearing the characteristics of psychological and psychoanalytic criticism. What's more, other critics, such as Richmond emphasize the resemblance to other important novelists, such as Kafka, instead of the novel's psychoanalytic characteristics. Richmond states, "It ultimately flounders as an ingenious, but too deliberate exercise in slick psycho-criticism fixing on a father-son duel suggestive of much Kafka scholarship" (15). From this perspective, the novel manages to be sufficient for a study. On the other hand, Solotaroff's summary of the novel is concerned with the identity crisis from a psychoanalytic perspective:

There is the same drama of the heart under its burden of baffled love, aspiration, and guilt, the same stern payment for confusions and mistakes, the same brutal suffering that leads to the indication of the hero's true identity for the suffering of Wilhelm's "true soul" and his "heart's ultimate need" are one and the same. (94)

However, even Bellow has adverse thoughts about his protagonist. In one of his interviews, he states that Tommy is a sympathetic but not respected: "I can sympathize with Wilhelm but I can't respect him. He is a sufferer by vocation. I'm a resister by vocation" (Roudané and Bellow 279). After all, when examining the protagonist's attitudes and psychology, many critics disagree whether Tommy is a congenial character or not. Freedman purports that Tommy attracts the reader's attention and sympathy: "Tommy Wilhelm exacts our sympathy not because he was oppressed by an irresistible social force, but because he had been pathetically and farcically outwitted by a figure so indigenous to his environment that he emerged as an image of himself" (51-2). In this way, Bellow gives hints describes and the characteristics of a modern man inundated by issues and obstacles. According to Bouson, Tommy's attempts to be loved and sympathetic give hints about his personality. "In Seize the Day surface illuminates subsurface as Wilhelm's verbal pleas for sympathy shed light on the preverbal depths of his personality" (Bouson 64). However, some critics categorize the protagonist as a victim: "It really is true that Wilhelm belongs to the victim-group" (Kulshrestha 12). This wretched character makes the reader think that he is unable to survive in the current world. This study discusses the reasons for his behaviours and his perception of his milieu.

\section{Discussion}

Tommy is a very complicated protagonist whose manner behavior can be understood by a psychologist. As Leroux states, "peace, serenity, harmony seem dangerous opiates to ... Tommy Wilhelm" (13). Opdahl summarizes the novel as follows: 
Tommy Wilhelm, an ex-salesman down on his luck with a divorce and a mistress and a failed nerve, has been rejected by two fathers- his real one and a spurious one who cheats him - he stumbles out into the street, an angry and broken man. And there he sees the epitome of the life force that has done him in: in the "gassy air" of upper Broadway. (5)

When considering these conditions, it may be such psychological problem may be regarded as normal.

First, Tommy is confused and overwhelmed with the idea of the responsibility of being a family man. Jacobs asserts that Tommy "cannot make sense of his own life and is so bowed under by the burden of self that when he looks to the city it becomes an apt metaphor for his own confusion" (196). What's more, some critics think that Tommy is not intelligent enough to sustain his own life. In some of Bellow's novels, the protagonists have the same characteristics, as Bailey purports: "Leventhal and Wilhelm are not intelligent men; each idea and value is falteringly carved out of their relationships with others and the events which shape them" (67). Furthermore, the lack of Tommy's father's Dr. Adler's appreciation of him, the obligation to send alimony to his wife for his children and his inability to pursue his dream career can be considered the causes of his problems. On the other hand, from another perspective, Clements stresses Tommy's business life and depicts the protagonist as "a modern salesman lost in the business ethic who has his personal world collapse" (535). Yet, Tommy desires to change himself, which makes him think that he will be able to escape his unlucky life. His "longing for a new transcendent self" (Goldman 13), in fact, constitutes the main theme of the novel. Moreover, in this sense, one of the main reasons for Tommy's psychological illness is his family problems. Having abandoned his wife and sons, Tommy is alone in his world. He cannot stand the conception idea of a family owing to the disappointment failure of fulfilling his dreams.

The novel mostly emphasizes Tommy's anger toward his father. Whenever the protagonist tries to talk to his father, he fails and "in conversation with his father he was apt to lose control of himself" (Bellow 34). Tommy's father becomes the most important factor in shaping his characterization. Despite his obligation to send money to his wife and losing all his money, Dr. Adler remains the main obstacle to overcoming his problems.

However, one must not forget it must not be forgotten that the protagonist thinks, or judges, or compares in terms of his father's point of view. Throughout the novel, Tommy desperately wants to hear his father say, "I am proud of you!" This unspoken sentence, in fact, becomes a silent motto for his alter ego. For example, the fact that Tommy is less educated than the rest of his family makes him even more miserable when he thinks of his father. "He was the only member of the family who had no education. This was another sore point. His father was ashamed of him" (Bellow 23). In this context, the lack of gratification from his father becomes a big problem. for him. More one example can be given of his quest for his father's approval: "It made Wilhelm profoundly bitter that his father should speak to him with such detachment about his welfare" (Bellow 13).

As mentioned, Tommy has his father's disposition to reflection. Regardless of his negative thoughts about his father, Tommy resembled him. Despite his anger and hatred of his father, he behaves as his father behaves toward him. In this respect, it is strange to behave like someone you dislike. For instance, upon being introduced to one of his father's friends, "'How d'do,' Wilhelm said. He did not welcome this stranger; he began at once to find fault with him" (Bellow 36). Looking for someone to blame, Tommy corresponds with his father. The only thing he finds out from his father is that he does not appreciate anybody for anything.

Tommy's father's issues, regardless of Tommy himself, are also a distinctive critical element to better understanding the novel. From the son's perspective, it is pathetic that Dr. Adler's recklessness turns into the main problem that leads to his mental distress. Furthermore, Dr. Adler's desire to live his own life is his motto, which the protagonist would also like to adopt:

Dr. Adler liked to appear affable. Affable! His own son, his one and only son, could not speak his mind or ease his heart to him. I wouldn't turn to Tamkin, he thought, if I could turn to him. At least Tamkin sympathizes with me and tries to give me a hand, whereas Dad doesn't want to be disturbed. (Bellow 13; emphasis mine)

As mentioned, since the novel deals with psychoanalytic criteria, the issue of the mother is very vague. Unlike Tommy's father, his mother is depicted as positive, sympathetic, and constructive: "From his mother he had gotten sensitive feelings, a soft heart, a brooding nature, a tendency to be confused under pressure" (Bellow 28). Furthermore, his deceased mother is the only person he can trust. His anger toward his father emerges from his father's attitudes to his mother, which Tommy thinks are inappropriate.

However, Dr. Adler is also another important figure in reshaping the protagonist. He Dr. Adler is handsome, sympathetic, and adored among his acquaintances. "The handsome old doctor stood well above the other old people in the hotel. He was idolized by everyone" (Bellow 14). Furthermore his hypercriticism is reflected in his description. His expressions, clothes, and attitudes have the manner of aristocracy, as Richmond purports: "What rescues Bellow's characterization from formula is the careful, even leisurely portrait of Dr. Adler: his dress, his gait, his thought, and his speech are presented with an exactness reminiscent of Henry James' insistence on the individuating detail" (16). On the other hand, he is pathetic in his inability it is pathetic that he is unable to be a father in the eyes of Tommy. While the protagonist cannot be regarded as a sane character depicted in the novel, his father's manner and attitudes are also aberrational for a parent.

Dr. Adler's way of finding fault with people in the protagonist's mind. Throughout the novel, many examples illustrate this: "Dr. Adler thought that Wilhelm looked particularly untidy this morning - unrested, too, his eyes redrimmed from 
excessive smoking" (Bellow 38). Furthermore, "before he struck the egg with his spoon he dried the moisture with his napkin. Then he battered it (in his father's opinion) more than was necessary" (Bellow 42). In this context, Dr. Adler's perfectionism distresses the protagonist. Above all, in addition to his feeling toward his son being sometimes regarded as inappropriate, he is portrayed as disliking his own son, making him very unlikable to the reader. For example, the novel teems with the sentences like that: "His father was ashamed of him." (Bellow 14). The distancing of his own son from himself is a normal characteristic of Dr. Adler, who is an egotist, a snob, and a perfectionist.

Sometimes Dr. Adler's perfectionism makes him perceive his son as a totally different person. Dr. Adler endeavors to introduce his son as a perfect person among his milieu: Tommy "had heard the old man bragging to another old man, saying, 'My son is a sales executive. He didn't have the patience to finish school'” (Bellow 14). The reason why he behaves thus way is because he believes his son must be a distinguished person like himself. This pressure damages the protagonist's personality. On the other hand, Dr. Adler despises his own child. By ignoring him, Dr. Adler dominates Tommy's inner world. Tommy succumbs to his father's hegemony and his desire to be appreciated turns into a vicious circle. Bellow indicates this situation when Dr. Adler thinks about his son with foul-mouthed words:

Wilhelm's preparations to please Dr. Adler had failed completely, for the old man kept thinking, You'd never guess he had a clean upbringing, and, What a dirty devil this son of mine is. Why can't he try to sweeten his appearance a little? Why does he want to drag himself like this? And he makes himself look so idealistic. (50, emphasis mine)

Dr. Adler's narcissism is another factor that forms his son's character. Dr. Adler is depicted as a narcissist who does not care for either of his children. His father's self-appreciation is so great and he cares about no one else that he shuffles the protagonist back to the obscurity of oscillating in his inner world. As Richmond purports, "Dr. Adler's vampiristic role and the complexity and machinery of New York City are the sources of the failed son's 'congested' emotional condition" (19, emphasis mine). On the one hand, Tommy's perspective feelings turns into repugnance and hatred in the novel. In fact, Tthe reason why he Dr. Adler is not interested in his son's problems is his narcissism and it causes an abysm between them. As Bouson states, "the conflict-ridden father-son confrontation that begins the novel gives the reader direct awareness of their colliding subjectivities and irresolvable differences" (67). This definite discrepancy is clearly observed throughout the novel. Besides, Dr. Adler considers everything his son's fault and his lack of sensitivity creates a divide between him and his son. The critic also describes how Tommy diverges away from his father thanks to his father's egocentrism:

Wilhelm acts out his desire to appropriate from his father the narcissistic sustenance he feels entitled to. When he, in his openly aggressive demands for sympathy, introduces his well-worn litany of complaints about his wife, Dr. Adler responds that it's Wilhelm's fault, that he doesn't understand his son's problems. (Bouson 69)

Tommy's perspective toward his father is also important in understanding his inner world. "Fair-haired hippopotamus! - that was how he looked to himself, He saw a big round face, a wide, flourishing red mouth, stump teeth" (Bellow 9). This profanity encapsulates the level of his sympathy to his father. There are also many attempts to attract his father's attention. "Another father might have appreciated how difficult this confession was-so much bad luck, weariness, weakness, and failure. Wilhelm had tried to copy the old man's tone and made himself sound gentlemanly, low-voiced, tasteful" (Bellow 13).

However, some critics assume that Dr. Adler's attitudes are rational owing to Tommy's childishness and mannerisms. His lack of responsibility and accusations of people around him verify clear his sophomoric behavior. In this sense, Tommy wants a second chance whenever he is supposed to be responsible. Wilson accuses him of acting immaturely:

Even a critic like Jonathan Wilson, who sees many of Dr. Adler's criticisms of Wilhelm as "to some extent justified" and who faults Wilhelm for acting like "an overgrown child," feels that "it is Wilhelm's childishness that primarily recommends itself to us." (Bellow 97, 100; quoted in Bouson 71)

Dr. Adler and his wife, Margaret, play an important role in shaping the protagonist's mind. Their recklessness and lack of empathy shuffle drift a deep ill psychology: "Indeed, as we shall see, critics have repeatedly pardoned Wilhelm for his faults and denounced his accusers Dr. Adler and Margaret for their unempathic treatment of him" (Bouson 67). However, as mentioned, Dr. Adler impresses affects his psychology very much. According to his interpretation, Bouson again summarizes the situation and Dr. Adler's relationship with his son:

In this father-son transaction we find important clues to Wilhelm's self-disorder. As we learn in this exchange, Wilhelm is acutely sensitive to what he perceives as his father's affective absence, his affable non-responsiveness, his self-absorption, his chronic faultfinding, and his covert demand that his son live up to his standards of perfection. (69)

However, Tommy, who is unable to get support from Dr. Adler, is in search of a similar consultant or a mastermind. For example, Venice, a talent scout, thinks that Tommy may as well be a movie star. Knowing his father does not support his desire to act, Tommy considers Venice a galvanizer of acting or an advisor for his histrionic life. In addition, Venice, unlike Dr. Adler, has mutual feelings for Tommy, eager to be an actor: "Venice bragged so nervously and identified himself so scrupulously - the poor guy. He was the obscure failure of an aggressive and powerful clan. As such he had the greatest sympathy from Wilhelm" (Bellow 23). 
However, Dr. Tamkin, who deceives Tommy for money, turns into his ideal father. "Snubbed by his father, Wilhelm transfers onto Tamkin his need for support from an idealizable self-object" (Bouson 72). This idealism blinds the protagonist. Not finding what he expected, he seeks a father who never refuses him as a son. Dr. Tamkin is a doctor who knows the commodity markets well and understands how to earn a lot of money. He is also eager to help the protagonist. As the critic states, he is ready to take Dr. Adler's position:

Having left his wife and children, incapable of ex-acting a divorce in his continued dependence on his wife, incapable therefore of remarrying, Wilhelm has turned to his father for succor. He is adamantly rejected; the way back to childhood is closed. But the substitute father, the spurious "psychologist" Dr. Tamkin, emerges to take the real father's place as other swindlers had done before in Wilhelm's life. (Freedman 56)

Just to clarify, Dr. Tamkin is a defrauder and a charlatan who steals all of Tommy's money. As Richmond describes, "Shamans, then, were prophets, priests, poets, pseudo- or surrogate-father images.... In Bellow's terms, Dr. Tamkin is Tommy's 'elected' father" (22). It is also distinctive noteworthy that these adjectives used by Tommy relate to his psychological convalescence. "in Hebrew the word tam means 'perfect'; and Tamkin is more kin to Tommy than his own self-preserving father" (Richmond 22). In this sense, the protagonist considers himself healed by Dr. Tamkin. However, Fishman goes further and charges Dr. Tamkin of Machiavellianism: Rather than being a Machiavellian, it is more important to use "pseudoscientific jargon as a pretext to steal Tommy Wilhelm's last thousand dollars" (620).

Tommy, believing his father "cast me even then for a loser" (Bellow 24), prefers Dr. Tamkin as a father to Dr. Adler. In fact, although he knows that Dr. Tamkin is a charlatan and a swindler, Tommy settles on Dr. Tamkin who Tommy thinks that he is more indulgent and apprehensive. However,

In desperation, Tommy turns to Dr. Tamkin (their names link their destinies), though his father has warned him, and Tommy well knows, that Tamkin is a charlatan and a fraud. Tamkin offers him a way out of his financial impasse by persuading him to bet his last seven hundred dollars on lard futures in the commodity market, though Tommy knows absolutely nothing about them. When Tommy loses his money, Tamkin suddenly disappears. But Tamkin does represent a powerful life force. (Meyers 165)

Bellow rebukes Tommy to be a better individual. In this sense, Dr. Tamkin's skullduggery turns into a force to heal his ailing mental distress. Meyers underlines the points the situation, yet the condition becomes either Tommy's ruination or his inception, which will be dealt with later in this paper.

As mentioned, Tommy is a distinctive noteworthy character to exemplify a psychological text which is full of mental illness. Psychoanalysis and dissociative identity disorder (DID) are a few examples illness in the novel. As Rodrigues states, Seize the Day presents "a larger, more terrifying version of the hard, treacherous, aggressive world" (242) This aggressive world is a tough one that shapes both Tommy's inner and outer worlds. For instance, Bellow makes two references likening Tommy to a hippopotamus: weltering in a marsh and "the waters of the earth are going to roll over me" (Bellow 84). Alhadeff justifies Tommy's psychology and, in his opinion, Tommy sticks in the middle of his problems: "Wilhelm is drowning throughout the book; this is symbolized by his inability to catch his breath. His psyche eventually becomes immersed in the waters of the soul as 'Tommy' dissolves and gives way to the 'real' Wilhelm Adler" (18).

Furthermore, Tommy's late mother is an important factor in shaping his relationship with his milieu. Depicting a good portrait with of his mother, Tommy is decent boy. The only family member who supports his acting is his mother. However, Tommy blames his father for her death. Tommy is always reminded of her death when quarreling with his father: "He thought what business has he to complain to me of his mother's death?" (Bellow 33). On the other hand, there are examples of the maternity he craves. For instance, when he is terribly ill, his wife takes care of him and reads him one of Keats's poems. The poem reminds him of "the interjected world of the good mother" (Bouson 77).

Dissociative Identity Disorder is an important ailment that can be ascertained from the novel. When Wilhelm decides to be an actor, he uses the pseudonym Tommy. When he makes mistakes, however, he calls himself Wilky, as his parents did, which creates a split in his mind. For example, "he had never, however, succeeded in feeling like Tommy and in his soul had always remained Wilky. When he was drunk he reproached himself horribly as Wilky. 'You fool, you clunk, you Wilky!' he called himself' (Bellow 28). Moreover, he embraces Wilky's disappearance. In this regard, it is indicated to attempt to find solutions to his mental distress. This pseudonym is a cover for his inefficacy:

It was the description of the two souls that had awed him. In Tommy he saw the pretender. And even Wilky might not be himself. Might the name of his true soul be the one by which his old grandfather had called him-Velvel? (Bellow 83)

Additionally, the name Wilky morphs into a shelter that concedes his fault. Notwithstanding, as mentioned above, Tommy is unable to make decisions or take risks. In this sense, Wilky is, his unavoidable soul, as he asserts:

The aim of the false-self system is to sublimate the inner self as a purely subjective entity, one which is lacking an objective existence. Laing notes that, "except in certain possible safe moments the individual seeks to regard the whole of his objective existence as the expression of a false self." (p. 95) Wilhelm has gone so far as to actually change his name in accordance with the falsities which he is attempting to perpetrate. His self-evaluation is 
incorrect, however, 'Tommy' does not represent the "freedom of the person" but rather the destructive overemphasis of Adler's libidinous drives. 'Wilky' is his "inescapable self;" Bellow chronicles this recognition through a series of recurring "certain possible safe moments" (Laing) which ultimately save 'Wilky' from Tommy.' (Alhadeff 17)

Some critics characterize Tommy deal with Tommy's characterization in terms of Freud's definition of mind structure (id, ego, superego). In this sense, while the id represents Tommy, Wilhelm is the superego, which reminds him of his responsibilities and social domination. When the protagonist is criticized or confronted with unexpected conditions, he calls himself Wilky or Velvel, as his grandfather does. AccordinglyConcordantly, these two personas emerge in terms of the protagonist's prerequisite. On this issue, Solotaroff asserts,

The point of Wilhelm's suffering begins to emerge when Tamkin, another of Bellow's fascinating mixtures of hokum and insight, tells Wilhelm of the two souls inside each man. There is the "pretender soul" and the "true soul" the former the instrument of "egotism" and "social control," and the latter the searcher for love and truth that "pays the price" for the pretender's ways, that "suffers and gets sick" (94)

The last episode in the novel involves Tommy being reborn from his ashes; yet, the protagonist is not ready for his transformation. His selected father, Dr. Tamkin, offers two options: to seize the day or to otherwise submerge himself and drown in the water. The choice of life will not be easy for him. His problem is, in fact, related with ego and self: "The individual who would exert his freedom toward such transcendence will need great spiritual capabilities to begin with, and then hard discipline" (Klein 223). But Tommy is incapable of being accountable and responsibility. At the end of the novel, the protagonist interrogates himself. He finds himself in the middle of nothingness. His father's taking no account of him and his wife's regarding him as financing push him to deeper steeps. Tommy says to himself,

\begin{abstract}
"'What art thou?' Nothing. That's the answer. Nothing. In the heart of hearts-Nothing! So of course you can't stand that and want to be Something, and you try. But instead of being this Something, the man puts it over on everybody instead. You can't be that strict to yourself. You love a little. Like you have a dog" (Scissors!) "or give some money to a charity drive. Now that isn't love, is it? What is it? Egotism, pure and simple. It's a way to love the pretender soul. Vanity. Only vanity, is what it is. And social control. The interest of the pretender soul is the same as the interest of the social life, the society mechanism. This is the main tragedy of human life. Oh, it is terrible! Terrible! You are not free. Your own betrayer is inside of you and sells you out. You have to obey him like a state. $\mathrm{He}$ makes you work like a horse. And for what? For who?" (Bellow 81)
\end{abstract}

At the end of the novel, Tommy understands that he has lost all of his money. He goes to a church and sheds tears for a burial. The discharge brings him relief. It is, in fact, a lesson for the protagonist: "He closed Seize the Day also with a 'burial scene' - a strongly promising or optimistic one. He is given to taking leave of his heroes amid nature's invigorating currents" (Siegel and Bellow 162). However, this incidence inclines portrays of Wilhelm's improvement. Tommy is diminished and Wilhelm rises. The protagonist no longer hides behind the name of Tommy and faces his past. As Alhadeff states, "the 'true' Wilhelm is discovered with the final emergence of an integrated personality, however impoverished" (17). In this sense, in the novel, which describes a single day in the life of the protagonist, Tommy learns his lesson. Furthermore, that the reader has a positive impression of the protagonist is undisputable. Tommy, the unsympathetic loser, converts to Wilhelm, who indurates in the society. Bouson emphasizes his transformation as follows: "While the closure can be viewed as a reparative gesture derived from Bellow's need to rescue the troubled self of his anti-hero, it also can be read as a reaction formation against his covert desire to 'kill off' his hapless character" (80, emphasis mine).

\title{
3. Conclusion
}

Throughout the novel, Tommy is in a process of metamorphosis that turns him back into Wilhelm. He is continually confronted with problems the average person must solve. In this regard, he feels the need to get rid of Tom[my], which symbolizes his id. Bancroft associates Tommy's problems with Freudian discourse: "In the post-Freudian world, we take hold of the self and attempt to wrestle it into submission. In Bellow's world, people physically escape to learn of themselves" (78). Similarly, it can be defined as a double personality and this personality cracks and Tommy turns to his own himself. The struggle in his inner world is a kind of stimulus which makes him healthier and more relief from his mental scars.

On the other hand, in writing such a novel, Bellow indicates the characteristics a decent person must have. A critic of Bellow's novels, Clements compares Malamud's Assistant with Seize the Day: "Both novels were useful in broadening the issue of acculturation to that of the moral question of what a good man does in a diverse, urban, and competitive society" (534). In sum, the novel is a distinctive elucidation of the protagonist's complicated psychology and one of the best American novels written by Saul Bellow.

\section{References}

Alhadeff, B. (1977). The Divided Self: A Laingian Interpretation of Seize the Day. Studies in American Jewish Literature 3/1, 16-20 
Allen, B. (2001) The Adventures of Saul Bellow. Hudson Review, 54/1, 77-87.

Bailey, J. M. (1973). The Qualified Affirmation of Saul Bellow's Recent Work. Journal of American Studies, 7/1, 6776.

Bancroft, M. (1984). Recommended: Saul Bellow. English Journal, 73/4, 77-78.

Bellow, S. (2001). Seize the Day. London: Penguin Books.

Bouson, J. B. (1989). The Empathic Reader: A Study of the Narcissistic Character and the Drama of the Self. Amherst: The University of Massachusetts Press.

Cheuse, A. (2006). A Tribute to Saul Bellow. World Literature Today 80/3. 19.

Clements, C. C. Jr. (1973). A Flag of Many Colors: American Ethnic Writing and Ethnic Studies. College English, 34/4. 531-536.

Fishman, E. (1983). Saul Bellow’s 'Likely Stories.' Journal of Politics 45/3. 615-634.

Freedman, R. (1960). Saul Bellow: The Illusion of Environment. Wisconsin Studies in Contemporary Literature, 1/1, 50-65.

Goldman, M. (1981). Humboldt's Gift and the Case of the Split Protagonist. Modern Language Studies, 11/2, 3-16.

Jacobs, R. D. (1977). 'Truths on the Side of Life': Saul Bellow, Nobel Prize 1976. World Literature Today, 51/2, 194197.

Klein, M. (1962). A Discipline of Nobility: Saul Bellow's Fiction. Kenyon Review, 24/2, 203-26.

Kulshrestha, C. (1972). A Conversation with Saul Bellow. Chicago Review, 23/ 4, 7-15.

Leroux, J.F. (2008). Exhausting Ennui: Bellow, Dostoevsky, and the Literature of Boredom. College Literature 35/1, $1-15$.

Meyers, J. (2009). Bluebeard Bellow. Kenyon Review, New Series, 31/2, 160-186.

Opdahl, K. M. (1979). 'Strange Things, Savage Things': Saul Bellow's Hidden Theme. Iowa Review, 10/4, 1-15.

Richmond, L. J. (1973). The Maladroit, the Medico, and the Magician: Saul Bellow's Seize the Day. Twentieth Century Literature, 19/1, 15-26.

Rodrigues, E. L. (1971). Bellow's Africa. American Literature, 43/2. 242-256.

Roudané, M. C. \& Bellow S. (1984). An Interview with Saul Bellow. Contemporary Literature, 25/3, $265-280$.

Siegel, B.\& Bellow S. (1978). Artists and Opportunists in Saul Bellow's 'Humboldt's Gift.' Contemporary Literature 19/2. 143-164.

Solotaroff, T. (1959). Philip Roth and the Jewish Moralists. Chicago Review 13/4, 87-99. 